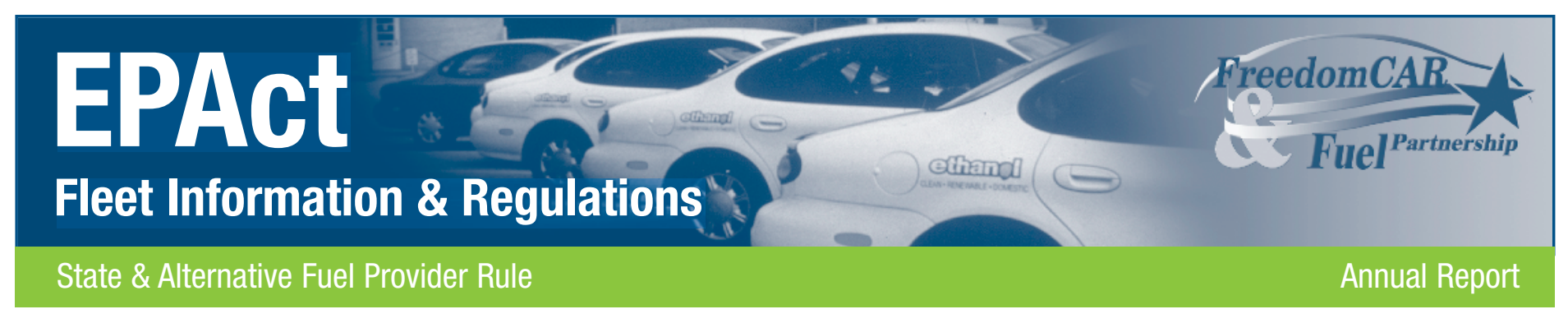

\title{
Activities and Accomplishments in MY 2004/FY 2005
}

In model year (MY) 2004, covered state and alternative fuel provider (S\&FP) fleets that report to the U.S. Department of Energy (DOE) complied with Energy Policy Act of 1992 (EPAct) fleet provisions (10 CFR Part 490) by:

- Acquiring more than 7,800 alternative fuel vehicles (AFVs)

- Earning 1,600 biodiesel credits

- Trading more than 1,300 AFV credits.

Results published in this report show that fleets continue to successfully meet their EPAct requirements by using alternative fuel technologies. The S\&FP program continues to see increases in biodiesel use and credit purchases by covered fleets. Additionally, the need for exemptions fell and, for the first time in several years, the number of new light-duty vehicles (LDVs) acquired by fleets increased, as fleets appear to be buying a higher proportion of new vehicles.

\section{Status of Covered Fleets}

In MY 2004, all 314 entities covered by the S\&FP program reported to DOE and were largely compliant with the requirements. Some entities represent one agency or business; others constitute fleet operations for an entire state. This outstanding level of compliance is credited to the many ways fleets are allowed to meet their requirements, including acquiring light-duty AFVs, purchasing credits from other fleets, using banked credits, and buying biodiesel.

\section{Vehicle Acquisitions}

AFV acquisition is the predominate method of compliance. Under S\&FP regulations, $75 \%$ of new covered LDVs acquired by state fleets must be AFVs, while $90 \%$ of LDVs acquired by alternative fuel providers must be AFVs. AFV acquisition requirements are determined by multiplying a fleet's number of newly acquired, non-excluded LDVs by the applicable percentages. In MY 2004, the number of covered LDV acquisitions was 13,374 , up almost $8 \%$ from the previous year. The number of AFV acquisitions required by the program was 10,266.

In MY 2004, covered fleets acquired 7,811 AFVs-a $5 \%$ drop from the previous year. This decrease is the result of fleets using flexible options, such as purchasing more credits, using more banked credits, and buying more biodiesel than in the past. Figure 1 shows the breakdown of AFV acquisitions by state and alternative fuel provider fleets.

\section{Credit Use and Purchase}

Covered fleets earn bankable credits by acquiring more AFVs than required. In MY 2004, fleets exceeded their AFV requirements, earning 2,104 credits. These credits can be banked for future compliance or sold to other fleets. In MY 2004, fleets used 2,744 banked credits to comply with EPAct—an 11\% increase over MY 2003.

Figure 1.

Number of AFVs Acquired

(by Covered Fleet Categories)

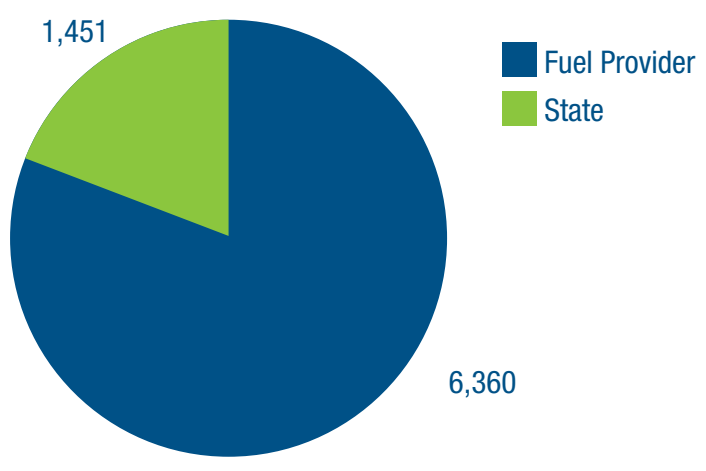


These credits helped fleets satisfy almost $25 \%$ of their MY 2004 AFV requirements.

Twenty-four fleets purchased banked credits from other fleets to help them offset their AFV acquisition requirements. In all, 1,312 credits were purchased in MY 2004 compared to 1,237 in MY 2003 - a 6\% increase. Figure 2 shows consistent growth in credit purchases since 2000 .

\section{Biodiesel Fuel Use}

Fleets can earn one credit for each 450 gallons of pure biodiesel (B100) they use or one credit for every 2,250 gallons of B20* (see 10 CFR 490.701-702). For the fifth consecutive year, biodiesel fuel use grew. In MY 2004, fleets used more than 2.4 million gallons of B100 for B20 blends compared to 2.2 million gallons in MY 2003-a $10 \%$ increase. Biodiesel credits accounted for nearly $15 \%$ of AFV requirements in MY 2004, with fleets earning a total of 1,671 biodiesel credits. The credits awarded don't reflect the amount purchased because fleets can use biodiesel to meet only $50 \%$ of their annual requirements.

The number of fleets that used biodiesel also increased from 79 to 81 , or $26 \%$ of all covered fleets. Twenty-eight state fleets reported using 865,485 gallons of biodiesel in MY 2004, while 53 alternative fuel provider fleets used just less than 1.6 million gallons. Although Figure 3 shows fuel providers to be the predominate users of biodiesel, state fleet use has also increased.

\section{Exemptions}

For the third year in a row, exemptions granted to fleets fell. In MY 2004, 28 fleets received 540 vehicle exemptions - $31 \%$ fewer than the 782 granted in MY 2003. This decline is due to an increase in the availability and use of biodiesel, credit purchasing, and outreach efforts instructing fleets to explore other compliance options before applying for exemptions. (This is detailed in the addendum to "Documentation Requirements for Exemption Requests," which is available on the EPAct website at www.eere.energy.gov/ vehiclesandfuels/epact/pdfs/exemption_addendum2.pdf.)

Exemptions granted in MY 2004 were minimal and reduced the total number of AFVs acquired by only about $6 \%-1 \%$ less than the previous year.
Figure 2.
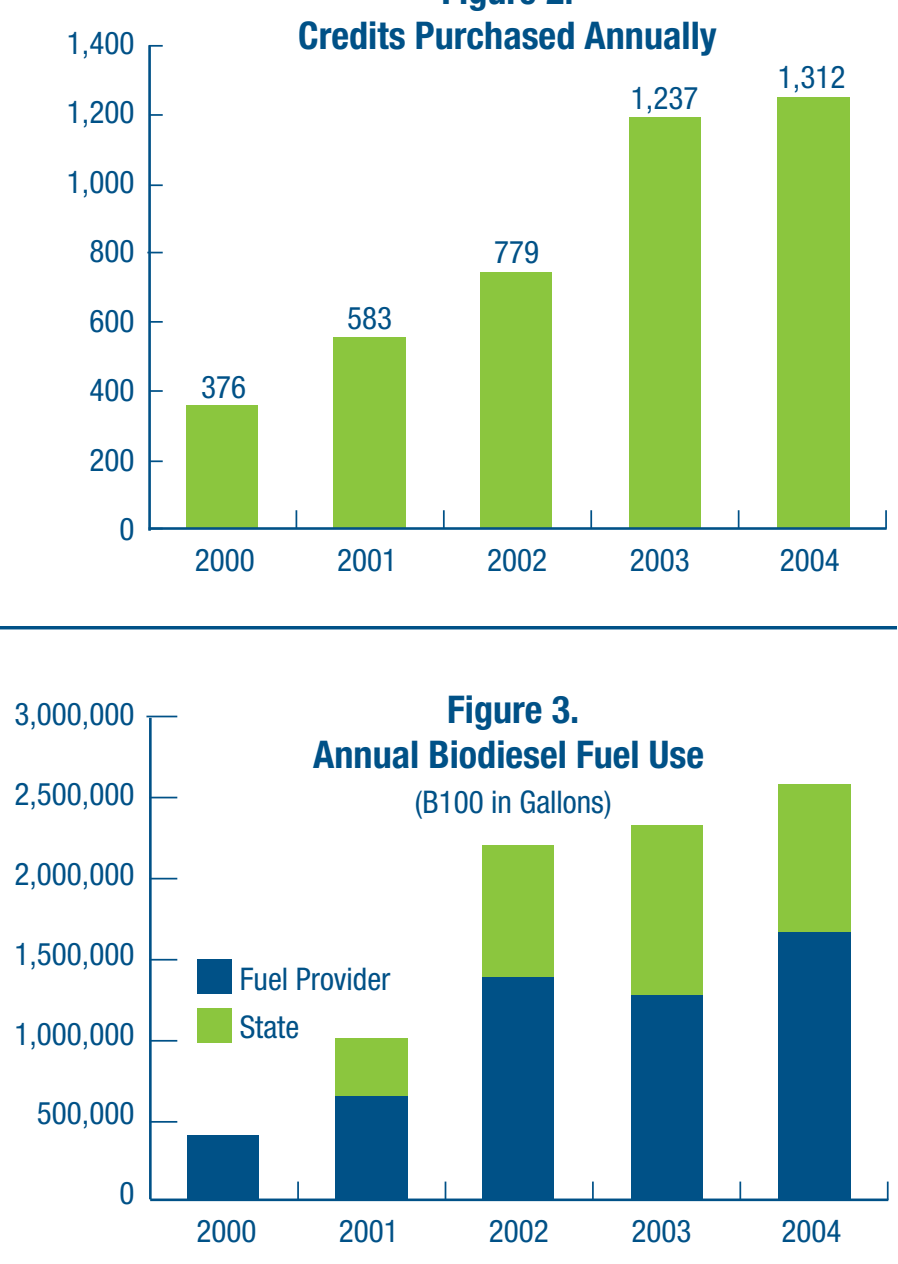

\section{Program Activities and Accomplishments}

In FY 2005, DOE continued to work with fleets to increase the number of AFVs acquired and expand the use of alternative fuels. Efforts included:

\section{Stakeholder Education}

During FY 2005, the S\&FP team worked toward determining whether all state fleets that must comply with EPAct were doing so. As a result, 30 new fleets were added to the program. In FY 2006, the team will focus on ensuring that all covered alternative fuel provider fleets are reporting to DOE.

\footnotetext{
* For more information on how biodiesel credits are calculated, download "Reporting Biodiesel Fuel Use Credits" from the EPAct website (www.eere.energy.gov/vehiclesandfuels/epact/pdfs/biodiesel_guidance.pdf).
} 
Also in FY 2005, the S\&FP team launched the E85 Fleet Toolkit, a comprehensive online guide that walks users through the installation of E85 fueling infrastructure. Completed in spring 2005, the toolkit is accessible on the Alternative Fuels Data Center website (www.eere.energy.gov/afdc/e85toolkit).

Additionally, the team published five documents detailing successful AFV programs in Minnesota, Missouri, New York, North Carolina, and Washington, D.C. The documents feature lessons state fleets learned from establishing AFV infrastructure. These publications are available on the EPAct website (www.eere.energy.gov/vehiclesandfuels/epact/state/ state_resources.shtml\#success).

\section{Communication with Covered Fleets}

The S\&FP team in FY 2005 continued to interact with fleets. Communications included a bi-annual newsletter, this annual report, program announcements, reporting reminders, and letters to fleets that failed to file timely reports. Fleets with credit deficiencies were also sent letters that summarized their compliance status and what they should do to resolve deficiencies. Fleets that didn't respond to these notices were contacted directly.

\section{Presentations at Conferences and Workshops}

In FY 2005, the S\&FP team exhibited at the National Biodiesel Board's Biodiesel Conference \& Expo in Fort Lauderdale, Florida. The team also unveiled a new exhibit at the 11th Annual Clean Cities Conference (CCC) in Palm Springs, California. Also at CCC, the S\&FP team hosted a session for Clean Cities coordinators and other participants, which addressed the benefits of regulated and voluntary fleets working together to meet common alternative fuel-related goals.

\begin{tabular}{|l|c|}
\hline \multicolumn{2}{|c|}{ Table 1. AFVs Acquired in MY 2004 } \\
\hline Light-Duty Sedans & $44 \%$ \\
\hline Light-Duty Pickups & $29 \%$ \\
\hline Minivans & $7 \%$ \\
\hline Sport Utility Vehicles & $14 \%$ \\
\hline Full-Sized Vans & $2 \%$ \\
\hline Medium-Duty Trucks & $4 \%$ \\
\hline
\end{tabular}

\section{Fleet Fuel Preferences}

In MY 2004, FFVs that can run on E85 accounted for $69 \%$ of newly acquired AFVs. Natural gas vehicles came in second at $21 \%$, followed by propane vehicles at $8 \%$. Interestingly, these percentages are practically level with the previous year's AFV breakdown of $65 \%, 24 \%$, and $7 \%$ respectively.

As in previous years, state fleets purchased a larger proportion of the FFVs acquired in MY 2004. Although many areas have limited E85 fueling infrastructure, several state fleets voluntarily added onsite stations and instructed drivers to use ethanol in their vehicles. In fact, many states (such as Idaho, Illinois, Minnesota, and Missouri) are establishing policies to encourage the use of E85 in fleet FFVs - a trend DOE expects to continue. At the same time, the number of E85 fueling sites in the United States doubled, bringing the total to more than 400 (a third of which are in Minnesota).

Some alternative fuel providers are also using E85 in their vehicles. Even though only $9 \%$ of the vehicles they purchased in MY 2004 were FFVs, DOE estimates that a dozen utilities installed their own E85 fueling sites within the last two to three years.

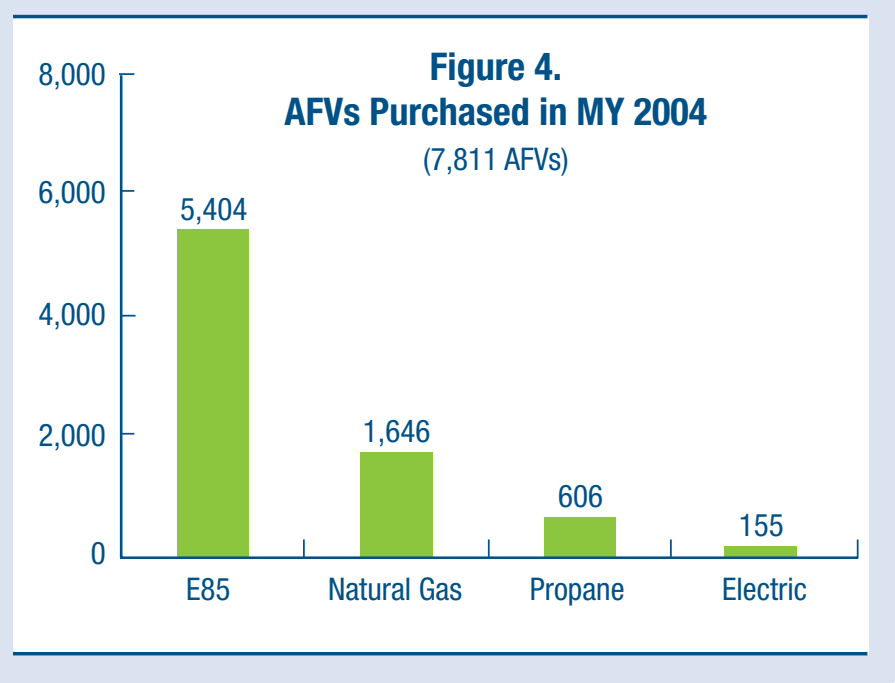




\section{Future Activities}

In August 2005, President Bush signed the Energy Policy Act of 2005. In FY 2006, the S\&FP team will review the policy and develop guidance for fleets to prepare for possible implementation of new options in MY 2007.

Also in FY 2006, the team plans to attend the National Conference of State Fleet Administrators in Coeur d'Alene, Idaho, and other industry functions. Events like this offer the S\&FP team the opportunity to interact with fleets and help them with regulation and compliance questions.

\section{Conclusion}

In MY 2004, covered fleets were extremely successful in their efforts to comply with S\&FP requirements. As part of their compliance efforts, covered fleets in MY 2004 acquired 7,811 AFVs and consumed more than 2.4 million gallons of biodiesel. All fleets have reported, and a handful of fleets with deficiencies have developed strategies to resolve them. The program has maintained its outreach efforts by visiting a number of covered and potentially covered fleets, developing a web toolkit for ethanol infrastructure planning, and participating in regional and national workshops and events.
Table 2. MY 2004 Highlights

\begin{tabular}{|l|c|}
\hline AFVs Purchased & 7,811 \\
\hline Banked Credits Used & 2,744 \\
\hline Credits Purchased & 1,312 \\
\hline Biodiesel Used (in Gallons) & 2.4 million \\
\hline Biodiesel Credits Awarded & 1,671 \\
\hline
\end{tabular}

\section{What Is EPAct?}

The Energy Policy Act of 1992 (EPAct) was passed by Congress to reduce the nation's dependence on imported petroleum. Provisions of EPAct require certain fleets to purchase AFVs. DOE administers these requirements through its State \& Fuel Provider Rule, Federal Fleet Rule, and Alternative Fuel Designation Authority.

For more information, visit www.eere.energy.gov/vehiclesandfuels/ epact, or call the Regulatory Information Line at 202-586-9171.
Sponsored by the U.S. Department of Energy

Energy Efficiency and Renewable Energy

FreedomCAR and Vehicle Technologies Program

For more information contact: EERE Information Center 1-877-EERE-INF (1-877-337-3463)

www.eere.energy.gov

A Strong Energy Portfolio for a Strong America

Energy efficiency and clean, renewable energy will mean a stronger economy, a cleaner environment, and greater energy independence for America. Working with a wide array of state, community, industry, and university partners, the U.S. Department of Energy's Office of Energy Efficiency and Renewable Energy invests in a diverse portfolio of energy technologies.

DOE/GO-102005-2172 • October 2005
Prepared by the National Renewable Energy Laboratory (NREL)

NREL is a U.S. Department of Energy National Laboratory

Operated by Midwest Research Institute $\bullet$ Battelle

Neither the United States government nor any agency thereof, nor any of their employees, makes any warranty, express or implied, or assumes any legal liability or responsibility for the accuracy, completeness, or usefulness of any information, apparatus, product, or process disclosed, or represents that its use would not infringe privately owned rights. Reference herein to any specific commercial product, process, or service by trade name, trademark, manufacturer, or otherwise does not necessarily constitute or imply its endorsement, recommendation, or favoring by the United States government or any agency thereof. The views and opinions of authors expressed herein do not necessarily state or reflect those of the United States government or any agency thereof.

Printed with a renewable-source ink on paper containing at least $50 \%$ wastepaper, including $20 \%$ postconsumer waste 